原著

\title{
早期胃癌に対する噴門側胃切除における食道残胃吻合法と 空腸囊間置法の比較検討
}

\author{
熊本市医師会熊本地域医療センター外科 \\ 沖野哲也蔵元一崇木村有 \\ 田上弘文稲吉厚八木泰志
}

1996年から2006年に当院で行った早期胃癌に対する噴門側胃切除後の食道残胃吻合法 22例 (EG 群) と，空腸囊間置法14例 (JPI 群) を対象とし比較検討した。手術時間は EG 群が有意に短く (EG 群：JPI 群=133分：161分), 出血量, 術後在院日数は両群で有意 差はなかった。縫合不全, 狭窄, 膵炎, 腸閉塞, 肺炎等の術後合併症や，胸やけ，つか え感, 嘔吐, 下痢, ダンピング症状等の術後愁訴, また食事摂取量, 術後体重減少, 術 後栄養指標変動においても両群間に有意差はなかった。術後 1 年目の内視鏡検査では食 道炎, 残胃炎, 狭窄, 胆汁逆流において両群に有意差はなかったが, 食物残渣の残存は $\mathrm{EG}$ 群が有意に少なく(EG 群：JPI 群=14.3\%：80.0\%), JPI 群の食物残渣は大部分が 間置空腸囊内に認められた。今回の検討では EG 群と比べ JPI 群に良好な成績は得られ ず, 手術時間, 食物残渣量の点で $\mathrm{EG}$ 群の成績が良好であり, 噴門側胃切除後の再建には 簡便で従来の食道残胃吻合法が望ましいと考えられる。

索引用語：早期胃癌, 噴門側胃切除術, 食道残胃吻合法, 空腸囊間置法

\section{緒言}

噴門側胃切除後の再建には, 開院以来主として食道 残胃吻合法 (esophagogastrostomy；以下 EG) を行っ てきたが，1990年代半ばより空腸囊間置法の有用性が 報告 ${ }^{1)}$ されるようになり, 逆流性食道炎を防ぎ, 食事摂 取量増大を期待して, 当院でも1996年より空腸囊間置 法（jejunal pouch interposition；以下 JPI）を取り入 れてきた。今回，われわれは早期胃癌に対する噴門側 胃切除後の quality of life（以下 QOL）について，同 時期に行った両再建法を比較し検討を行ったので報告 する。

\section{研究対象および方法}

\section{1. 対象}

1996年から2006年に当院で行った噴門側胃切除術の うち，進行胃癌や悪性リンパ腫等を除外し，かつ内視 鏡的切除不可能な噴門部早期胃癌に対する噴門側胃切 除後の再建法として，食道残胃吻合を行った22例 (EG

2007 年 6 月 29 日受付 2007 年10月16日採用

〈所属施設住所〉

于860-0811 熊本市本荘 5-16-10
群) と，空腸囊間置を行った14例 (JPI 群) を対象とし た。術式の選択は無作為ではなく, 主として長期生存 が期待できる比較的若年者に QOL の向上を期待して 空腸囊間置法を選択した。

\section{2 . 検討項目}

1 ) 手術侵襲: 手術時間, 出血量, 術後在院日数.

2 ) 術後合併症（術後在院期間）：縫合不全, 狭窄, 膵炎，腸閉塞，肺炎.

3 ) 術後愁訴（術後在院期間および術後 1 年）：胸や け，つかえ感，嘔吐，下痢，ダンピング症状。なお術 後 1 年のデータは当院での経過観察が可能であった症 例（EG 群；n=9，JPI群； $\mathrm{n}=11$ ）を対象とした。

4 ）食事摂取量：術後在院期間の全粥捸取時におけ る 1 回摂取量を比較した。

5 ）術後内視鏡所見：食道炎，食物残渣残存，残胃 炎, 狭窄, 胆汁逆流。術後 1 年目に当院で内視鏡検查 を施行した症例 (EG 群; $\mathrm{n}=7$, JPI 群 ; $\mathrm{n}=10$ ) を対 象とした。なお，全例通常通り内視鏡検査前日の夕食 まで摂取し，以後絶食とし，当日は午前中に検査を行 つた.

6 ) 栄養指標変動：体重変動, Hb, 血清 TP, Alb, 
T-chol の変動. 術後体重減少に関して, 術後半年, 術 後 1 年に当院での経過観察が可能であった症例（EG 群；n=6,JPI 群；n=11）にを対象とした.また, Hb， 血清 TP, Alb, T-chol の術後変動に関しては, 術後 1 年に当院での経過観察が可能であった症例（EG 群； $\mathrm{n}=5$ ，JPI 群； $\mathrm{n}=5$ ）を対象とした.

なお，検討項目 1)～6）については，診療記録（術 後在院期間は入院カルテ，術後 1 年は外来カルテ）よ り検討した。

\section{3 . 術式}

胃切離線は両群とも小彎側が胃角部，大彎側が大彎 線に沿って ECJ から $10 \mathrm{~cm}$ 肛門側の部位を基本とし, 残胃の大きさは $2 / 3$ 程度であった.リンパ節郭清は両群 とも No.1, 2, 3 ,4s, 7, 8a, 9 とし, M 癌では No.8a, 9 は省略した。迷走神経は両群とも前幹, 後幹を切除 した。

EG 群の食道残胃吻合は残胃前壁に端側で, JPI 群の 食道空腸囊吻合は空腸囊の頂点より $2 \sim 3 \mathrm{~cm}$ 右側の 腸間膜対側に端側で，ともに $25 \mathrm{~mm}$ 径の自動吻合器を 用いて行った．空腸囊の長さは $10 \sim 20 \mathrm{~cm}$ (平均 13.9 $\mathrm{cm})$ であり, 空腸囊残胃吻合は手縫いで行った。なお, 空腸囊の腸間膜処理は直動脈のみ $1 \sim 2$ 本結紮, 切離 し，辺縁動脈は温存した。

幽門形成は EG 群22例中 8 例, JPI 群14例中 2 例に 施行した (両群間に有意差なし). 非施行例には用手的 な幽門輪の拡張を行った. His 角形成等の逆流防止策 (Belsey Mark IV 法に準じた噴門形成術 $\left.{ }^{2}\right)$ は EG 群 22例中 3 例にのみ行い, JPI 群14例には行わなかった (両群間に有意差なし)。両再建法のシェーマを示す (図 1 ).

\section{4. 統計学的処理}

有意差検定は Mann-Whitney の U 検定またはカイ 二乗検定で行い， $5 \%$ の危険率をもって有意差ありと した。得られたデー夕は平均值士標準偏差で表した。

\section{1. 背景因子}

両群の背景因子を表 1 亿示す。年齢は EG 群が $68.0 \pm 9.1$ 歳，JPI 群が57.4土13.8歳で，EG 群の方が JPI 群と比べて有意に高齢であった $(\mathrm{p}=0.004)$. 性別 は EG 群が男性20例, 女性 2 例, JPI 群が男性 9 例, 女 性 5 例で両群間に有意差はなかった。また深達度も $\mathrm{EG}$ 群は $\mathrm{m}$ が 8 例， sm が14例，JPI 群は $\mathrm{m} ， \mathrm{sm}$ とも 7 例で両群間に有意差はなかった。

2 . 手術侵襲 両群の手術侵襲を表 2 に示す。手術時
間に関して,EG 群が $131 \pm 28$ 分, JPI 群が161 121 分で, $\mathrm{EG}$ 群の方が JPI 群と比べて有意に手術時間が短かっ た $(\mathrm{p}=0.001)$. 出血量, 術後在院日数に両群間に有意 差はなかった。

\section{3 . 術後合併症（術後在院期間）}

胸やけ, つかえ感, 嘔吐, 下痢, ダンピング症状に 関し，両群間に有意差はなかった(表 3 )。なお，術後 在院期間に狭窄が認められた $\mathrm{EG}$ 群の 3 例のうち 2 例 （食道残胃吻合部）に内視鏡的バルーン拡張術を要し た. 術後在院期間に JPI 群は内視鏡的バルーン拡張術 は要さなかった。

\section{4. 術後愁訴（術後在院期間および術後 1 年）}

術後愁訴に関して, 術後在院期間, 術後 1 年とも胸 やけ, つかえ感, 嘔吐, 下痢, ダンピング症状に両群 間に有意差はなかった（表 4 ）。

\section{5 . 食事撖取量}

術後在院期間の全弹摂取時における 1 回摂取量は EG 群が7.0土2.0割, JPI 群が5.8割土1.6割で, 両群間 に有意差はなかった（表 5 ).

なお，狭窄のため内視鏡的バルーン拡張術を要した $\mathrm{EG}$ 群の 2 例については, 拡張術後の全弹摂取量とし た.

\section{6.内視鏡所見（術後 1 年）}

内視鏡所見 (術後 1 年) に関して，食道炎，残胃炎， 狭窄, 胆汁逆流は両群間に有意差はなかった。食道炎 を認めた EG 群の 2 例は Los Angeles 分類 Grade C とAであり，JPI 群の 1 例は Grade B であった。

食物残渣の残存は EG 群が 7 例中 1 例 (14.3\%), JPI 群が10例中 8 例 (80.0\%) で，EG 群は JPI 群と比べて 有意に少なかった $(\mathrm{p}=0.008)$ （表 6 ）。しかも，JPI 群 で食物残渣の残存が認められた 8 例中 7 例が空腸囊内 に認められた（図 2 ).

\section{7 . 栄養指標変動}

術後体重減少に関して, 術後半年, 術後 1 年とも両 群間に有意差はなかった(表 7 )。また，血清 TP, Alb, $\mathrm{T}-\mathrm{chol}, \mathrm{Hb}$ の術後変動 (術後 1 年) に関して, 両群間 に有意差はなかった。

\section{考察}

噴門側胃切除後の再建には，当院の開院以来主とし て食道残胃吻合法を行ってきたが，1990年代半ばより 空腸囊間置法の有用性が報告1)されるようになり，逆 流性食道炎を防ぎ，食事摂取量増大を期待して，1996 年より空腸囊間置法を取り入れてきた。噴門側胃切除 術後の再建法別による比較検討を行った報告もなさ 


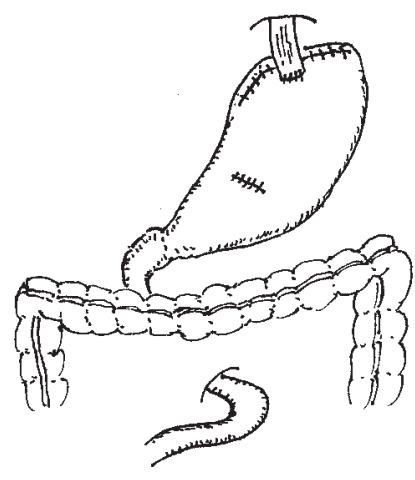

EG

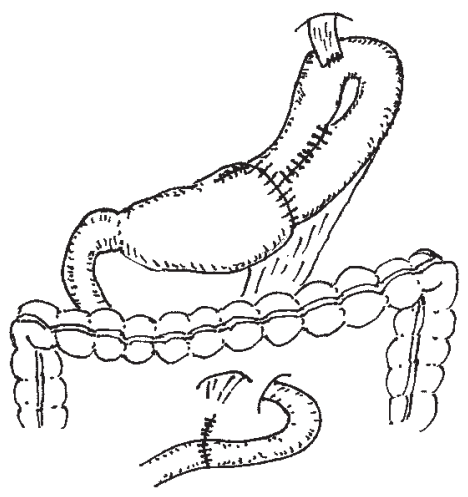

JPI

図 1 再建術式：両群の残胃の大きさは同じで, pouch の長さは $10 ２ 0 \mathrm{~cm}$ (平均 $13.9 \mathrm{~cm})$ であった。

表 1 背景因子

\begin{tabular}{cccc}
\hline & EG 群 $(\mathrm{n}=22)$ & JPI 群 $(\mathrm{n}=14)$ & $\mathrm{p}$-value \\
\hline 年齢 (歳) & $68.0 \pm 9.1$ & $57.4 \pm 13.8$ & $\mathrm{p}=0.004$ \\
性別 $(\mathrm{M} / \mathrm{F})$ & $20 / 2$ & $9 / 5$ & $\mathrm{n} . \mathrm{s}$. \\
深達度 $(\mathrm{m} / \mathrm{sm})$ & $8 / 14$ & $7 / 7$ & n. s. \\
\hline
\end{tabular}

年齢のみ JPI 群が有意に若年であった.

表 2 手術侵襲

\begin{tabular}{cccc}
\hline & EG 群 $(\mathrm{n}=22)$ & JPI 群 $(\mathrm{n}=14)$ & $\mathrm{p}$-value \\
\hline 手術時間 (分) & $131 \pm 28$ & $161 \pm 21$ & $\mathrm{p}=0.001$ \\
出血量 (グラム) & $346 \pm 347$ & $459 \pm 163$ & $\mathrm{n} . \mathrm{s}$. \\
術後在院日数 $($ 日) & $27.9 \pm 7.0$ & $29.2 \pm 7.1$ & $\mathrm{n} . \mathrm{s}$. \\
\hline & & 手術時間は EG 群が有意に短かった.
\end{tabular}

表 3 術後合併症（術後在院期間）

\begin{tabular}{|c|c|c|c|}
\hline & EG 群 $(\mathrm{n}=22)$ & JPI 群（n=14） & $\mathrm{p}^{\text {-value }}$ \\
\hline 縫合不全 & 0 & 0 & n. s. \\
\hline 狭窄 & $3 \quad(13.7 \%)$ & $2 \quad(14.3 \%)$ & n. s. \\
\hline 膵炎 & 0 & 0 & n. s. \\
\hline 腸閉塞 & $1 \quad(4.5 \%)$ & 0 & n. s. \\
\hline 肺炎 & $1 \quad(4.5 \%)$ & $1 \quad(7.1 \%)$ & n. s. \\
\hline
\end{tabular}

全ての因子で両群間に有意差はなかった.

れ, 食道残胃吻合法と空腸囊間置法 ${ }^{3)}$, 空腸間置法と空

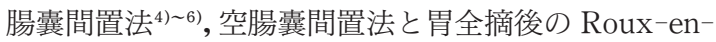
$\mathrm{Y}$ 法 ${ }^{7) 8)}$ との比較において, 空腸囊間置法が優れるとい う報告が多い。
今回，われわれは手術症例の条件を可能な限り一定 にするため，噴門側胃切除術を行った症例のうち早期 胃癌症例に限定して, 同時期に行った食道残胃吻合法 と空腸囊間置法を retrospectiveに比較し検討を行った。 
表 4 術後愁訴

\begin{tabular}{cccc|ccc}
\hline \multicolumn{4}{c}{ 術後在院期間 } & \multicolumn{3}{|c}{ 術後 1 年 } \\
\hline & $\begin{array}{c}\text { EG 群 } \\
(\mathrm{n}=22)\end{array}$ & $\begin{array}{c}\text { JPI 群 } \\
(\mathrm{n}=14)\end{array}$ & $\mathrm{p}$-value & $\begin{array}{c}\text { EG 群 } \\
(\mathrm{n}=9)\end{array}$ & $\begin{array}{c}\text { JPI 群 } \\
(\mathrm{n}=11)\end{array}$ & $\mathrm{p}^{-}$value \\
\hline 胸やけ & $4(18.2 \%)$ & $3(21.4 \%)$ & n. s. & $3(33.3 \%)$ & $5(45.4 \%)$ & n.s. \\
つかえ感 & $4(18.2 \%)$ & $4(28.6 \%)$ & n. s. & $3(33.3 \%)$ & $5(45.4 \%)$ & n.s. \\
嘔吐 & $2(9.1 \%)$ & $2(14.3 \%)$ & n. s. & 0 & $2(18.2 \%)$ & n.s. \\
下痢 & 0 & $2(14.3 \%)$ & n. s. & 0 & $2(18.2 \%)$ & n.s. \\
ダンピング症状 & 0 & 0 & n. s. & $1(11.1 \%)$ & 0 & n.s. \\
\hline
\end{tabular}

全ての因子で両群間に有意差はなかった。

表 5 食事摂取量（術後在院期間全粥摂取時）

\begin{tabular}{cccc}
\hline & $\mathrm{EG}$ 群 $(\mathrm{n}=22)$ & JPI 群 $(\mathrm{n}=14)$ & $\mathrm{p}$-value \\
\hline 食事摂取量 $($ 割 $)$ & $7.0 \pm 2.0$ & $5.8 \pm 1.6$ & $\mathrm{n} . \mathrm{s}$. \\
\hline & & 両群間に有意差はなかった.
\end{tabular}

表 6 内視鏡所見（術後 1 年）

\begin{tabular}{|c|c|c|c|}
\hline & $\mathrm{EG}$ 群 $(\mathrm{n}=7)$ & JPI 群 $(\mathrm{n}=10)$ & $\mathrm{p}^{-}$-value \\
\hline 食道炎 & $2 \quad(28.6 \%)$ & $1 \quad(10.0 \%)$ & n. s. \\
\hline 食物残渣残存 & $1 \quad(14.3 \%)$ & $8 \quad(80.0 \%)$ & $\mathrm{p}=0.008$ \\
\hline 残胃炎 & $2 \quad(28.6 \%)$ & $2 \quad(20.0 \%)$ & n. s. \\
\hline 狭窄 & 0 & $2(20.0 \%)$ & n. s. \\
\hline 胆汁逆流 & 0 & 0 & n. s. \\
\hline
\end{tabular}

食物残渣は JPI 群で有意に多く認めた。

\begin{tabular}{|c|c|c|c|c|}
\hline EG群 $(n=7)$ & \multicolumn{3}{|c|}{$\begin{array}{c}- \\
(86 \%)\end{array}$} & $\begin{array}{c}+ \\
(14 \%)\end{array}$ \\
\hline JPI群 $(n=10)$ & $\frac{-}{(20 \%)}$ & $\begin{array}{c}+ \\
(10 \%)\end{array}$ & $\begin{array}{l}++ \\
(30 \%)\end{array}$ & $\begin{array}{l}+++ \\
(40 \%)\end{array}$ \\
\hline $\begin{array}{l}\text { JPI群の残渣 } \\
\text { 存在部位 }\end{array}$ & \begin{tabular}{|c|} 
残胃のみ \\
$(12 \%)$ \\
\end{tabular} & pou & Dみ & $\begin{array}{c}\text { pouchと残贯 } \\
(38 \%)\end{array}$ \\
\hline
\end{tabular}

一;なし +; 少量 ++; 中等量 +++; 多量

JPI群の残渣は量が多く, 残胃よりもpouchに多く存在した.

\section{図 2 食物残渣の程度と存在部位}

背景因子のうち年齢については両群間で有意差が認 められ, JPI 群の方が若年であった (EG 群：JPI 群= 68.0歳： 57.4歳, $\mathrm{p}=0.004)$. 長期生存が期待できる比 較的若年者に QOL の向上を期待して, また, 大きくな ることが予想される手術侵襲にも十分耐えうる比較的
若年者に空腸囊間置法を多く選択する傾向があったこ とが原因と考えられる，手術時間は術式が単純である EG 群の方が当然短く, 有意差を認めた（EG 群：JPI 群 $=131$ 分：161分, $\mathrm{p}=0.001$ ).ただ，両群間の手術時 間の差は平均 30 分であり, 術後在院日数や術後経過に 
表 7 術後体重の推移（術前体重 $=100 \%)$

\begin{tabular}{lccc}
\hline & EG 群 $(\mathrm{n}=6)$ & JPI 群 $(\mathrm{n}=11)$ & $\mathrm{p}$-value \\
\hline 術後半年 $(\%)$ & $85.2 \pm 3.1$ & $86.6 \pm 5.5$ & $\mathrm{n} . \mathrm{s}$. \\
術後1 年 $(\%)$ & $86.2 \pm 2.6$ & $88.5 \pm 7.1$ & n.s. \\
\hline & \multicolumn{3}{r}{ 全ての因子で両群間に有意差はなかった. }
\end{tabular}

差がなかったことから，JPI 群の手術侵襲が過大とは 考えられなかった。

今回行った空腸囊間置法は Kameyama らの方法 ${ }^{11}$ に準じて行ったが，逆流性食道炎をきたしたのが27例 中 1 例 ${ }^{9}$ というような満足する成績は得られず，術後 1 年目の内視鏡検査で逆流性食道炎を $10.0 \%$ に, 胸や け症状を $45.5 \%$ に認めた。進行食道癌, アカラシア, 進行胃癌などの病変がなく，かつ上部消化管の手術既 往がない場合，胸やけ症状を有する症例のうち，ロサ ンゼルス分類 A〜Dの逆流性食道炎はわずか $14.3 \%$ であり，残りの $58.9 \%$ が Grade N（normal），26.8\% が Grade M (minimal change) であった ${ }^{10)}$.内視鏡 所見としての逆流性食道炎と自覚症状との間には解離 が大きいことが報告されている。今回噴門側胃切除術 を行って胸やけを訴えた患者においても，EG 群の33 $\%$ ( 3 例中 1 例)，JPI 群の $80 \%$ ( 5 例中 4 例) が Grade $\mathrm{N}$ に相当し，内視鏡的に逆流性食道炎は認められなか った. 大杉ら ${ }^{11}$ によれば, 胃切除後には胆汁逆流が存在 し, 酸逆流がない場合, ごく軽度の胆汁逆流のみでは, 逆流症状を訴えても食道に器質的病変は形成されない としている.

今回のわれわれの検討では, 胸やけ，つかえ感等の 術後愁訴は, 術後在院期間, 術後 1 年とも両群間にお いて統計上差は認められなかったが，食物残渣の残存 は術後 1 年の内視鏡検查で空腸囊間置症例に有意に多 く(EG 群：JPI 群 $=14.3 \%: 80.0 \%, \mathrm{p}=0.008), 10$ 例中 8 例と高率で，うち 8 例中 7 例は pouch 内に存在 した。噴門側胃切除後，幹迷切を行った場合には dysrhythmia が頻発する ${ }^{12)}$ が，幽門枝を温存すること により残胃の dysrhythmia を少なくでき ${ }^{13)}$, 残胃およ び幽門輪に分布する神経を温存した噴門側胃切除空腸 囊間置術を行うことにより十分な量の食事が可能であ ったことが報告されている ${ }^{14)}$ ．当院では迷走神経の前 幹, 後幹とも全症例切離したが, 迷走神経の肝枝沶よ び幽門枝を温存した施設でも，食物残渣を pouch 内に 多量 ${ }^{15)}$, pouch 内に $50 \%$ 認めていることから, 残渣の 原因は残胃よりもむしろ pouch にあることが示唆さ
れる。

また，残胃の大きさは両群間で差はなかったことか ら，JPI 群の方が EG 群と比べて pouch の分だけ貯留 能が多きいにもかかわらず高率につかえ感を訴えるの は，残渣が原因の一つと考えられる。

小腸は消化管の中で最も自律性の高い部位で，その 運動機能は基本的に消化管の内在神経叢である腸管神 経系 enteric nervous system ${ }^{16)}$ とって制御され，迷 走神経などの外来神経により運動の協調や調節を受け ている ${ }^{17)}$.しかしながら, 胃全摘後に有茎空腸を移植す る空腸間置術を行った慢性犬での研究では，間置空腸 に発生する伝播性筋放電群 migrating myoelectric complex と呼ばれる平滑筋の電気的活動が十二指腸 に伝播しないなど，再建にあたり腸管を切離，吻合や 転位することで間置空腸一十二指腸間に協調運動が認 められないことが確認され，このことが術後のもたれ 感, 胸やけの一因と考えられるとしている ${ }^{18)}$.この事実 を空腸囊間置術に置き換えると, 間置空腸囊に発生し た伝播性筋放電群が残胃に伝播せず，間置空腸囊－残 胃間の協調運動が認められないことが予想され，食物 の pouch 内の停滞などにより多量の残渣が残存する 原因の一つと考えられる。

なお，噴門側胃切除空腸囊間置術後，つかえ感や嘔 吐などの症状が強くなり, pouch および残胃からの高 度な排出障害を認め, pouch の不可逆的な高度拡張を きたし，保存的治療で改善が認められず，初回手術か ら 3 年後 ${ }^{19)}, 4$ 年半後 ${ }^{20)}$ に再手術を施行した例も報告 されている.

以上より，今回の検討では統計学的に EG 群と比べ JPI 群に良好な成績は得られなかった.EG 群において は術後 1 年目の内視鏡検査で逆流性食道炎を $28.6 \%$ に，胸やけ症状を $42.9 \%$ に認め，食道残胃吻合法を全 面的に肯定はできないが，手術時間が短く，食物残渣 残存が少ない点で EG 群の成績が良好であった。噴門 側胃切除後の再建法としては手技的に容易であり，最 も単純といえる食道残胃吻合法の方が満足しうる術式 であると考えられる。さらに，食道残胃吻合法におい 
て，His 角を形成し ${ }^{21)}$ かつ残胃の巻き付けを行う ${ }^{22)}$ 方 法や, 腹部食道を腹腔内に固定する ${ }^{23)}$ 方法などの, 食道 残胃の逆流予防の付加手術を加えることによって, 胸 やけなどの術後症状の軽減をよりいっそう図れるもの と考えられる。

\section{結 語}

今回のわれわれの検討は retrospective なもので, 食道残胃吻合法が明らかに優れるという結論には至ら ないが，手技的にも容易で支持しうる再建法と考えら れる。

なお, 本論文の要旨は第107回日本外科学会定期学術集会 （大阪）にて発表した。

\section{文献}

1) Kameyama J, Ishida $H$, Yasaku $Y$, et al : Proximal gastrectomy reconstructed by interposition of a jejunal pouch. Eur J Surg 159 : 491493, 1993

2）宮内好正，大熊利忠：滑脱型食道裂肛ヘルニアの 手術 Belsey Mark IV型噴門形成術および胃後壁 固定術を中心に. 手術 $41 ： 603$-608，1987

3) Hoshikawa T, Denno R, Ura H, et al: Proximal gastrectomy and jejunal pouch interposition: evaluation of postoperative symptoms and gastrointestinal hormone secretion. Oncol Rep 8:1293-1299, 2001

4）仙丸直人, 森田高行, 宮坂 祐他：噴門側胃切除 における空腸間置法と空腸囊間置法との比較検 討. 日消外会誌 $32 ： 2309-2313 ， 1999$

5）亀山仁史，梨本 篤，藪崎 裕他：噴門側胃切除 後の空腸間置術と空腸囊間置術の比較. 日臨外会 誌 $65 ： 2294-2298 ， 2004$

6) Iwata $\mathrm{T}$, Kurita $\mathrm{N}$, Ikemoto $\mathrm{T}$, et al: Evaluation of reconstruction after proximal gastrectomy: prospective comparative study of jejunal interposition and jejunal pouch interposition. Hepatogastroenterology $53: 301-303$, 2006

7）藪崎 裕, 梨本 篤, 田中乙雄他：U 領域早期胃 癌に対する噴門側胃切除, 空腸囊間置再建法の臨 床的検討. 日消外会誌 $34 ： 1568-1576 ， 2001$

8) Yoo CH, Sohn BH, Han WK, et al: Proximal gastrectomy reconstructed by jejunal pouch interposition for upper third gastric cancer: prospective randomized study. World J Surg
29 : 1592-1599, 2005

9）亀山仁一，鈴木 晃，石田一他：上部胃癌に対 する有茎空腸囊を間置した噴門側胃切除術一手技 と成績一. 外科治療 $76: 131-135,1997$

10）星原芳雄，山本 敬，橋本光代他：GERD の内視 鏡観察の指針と展開.消内視鏡 $12: 1525-1530$, 2000

11）大杉治司, 綛野 進, 高田信康他：GERD と胆汁 逆流一今後の展望. 消内視鏡 $12 ： 1517-1524$, 2000

12）渡部洋三，津村秀憲， 巾 尊宣他：幽門保存胃切 除術. 臨外 51：1255-1261，1996

13）梨本 篤, 藪崎 裕, 滝井康公他: 各種機能検查 からみた神経温存胃切除術の評価. 臨外 58 ： 1317-1323，2003

14) Tomita R, Fujisaki S, Tanjoh K, et al : A novel operative technique on proximal gastrectomy reconstructed by interposition of a jejunal $\mathrm{J}$ pouch with preservation of the vagal nerve and lower esophageal sphincter. Hepatogastroenterology $48: 1186-1191,2001$

15）野村栄治，仁木正己，谷川允彦他：器械吻合手技 の実際 噴門側胃切除後吻合 有茎空腸移植. 外 科 $61: 855-859,1999$

16) Langley JN : The autonomic nervous system, part 1 W. Heffer \& Sons Ltd., Cambridge, 1921

17）唐木晋一郎, 長浜正人, 桑原厚雄：胃, 小腸運動 一迷走神経, 腸管神経の関与. 今村朝雄, 胃切除 と再建術式, 医学図書出版, 東京, 2005, p23-50

18）松尾仁之：胃全摘空腸間置術後の消化管運動一慢 性犬を用いた実験的研究一.日外会誌 $90 ： 504-$ 512, 1989

19) Ueno $M$, Iwahashi $M$, Nakamori $M$, et al: Complication of jejunal pouch interposition after proximal gastrectomy : case report. Hepatogastroenterology $51: 916$-918, 2004

20) Katsube $T$, Konno S, Hamaguchi $K$, et al: Complications after proximal gastrectomy with jejunal pouch interposition: report of a case. Eur J Surg Oncol 31: 1036-1038, 2005

21）近藤泰理，柏木宏之，鈴木理香他：噴門側胃切除 に抢ける食道胃吻合法と逆流防止の工夫. 手術 58：213-217，2004 
22）石神純也，中条哲浩，上之園芳一他：食道残胃吻 合時の残胃の巻き付けと類 His 角形成による逆 流予防の工夫. 手術 61：243一245，2007

23）辻 秀樹, 安藤重満, 三井 章他: 下部食道の逆
流防止機能を温存した噴門側胃切除術後の quality of life に関する検討. 日消外会誌 $38: 377-$ 384, 2005

\title{
COMPARATIVE STUDIES BETWEEN ESOPHAGOGASTROSTOMY AND JEJUNAL POUCH INTERPOSITION AFTER PROXIMAL GASTRECTOMY FOR EARLY GASTRIC CANCER
}

\author{
Tetsuya OKINO, Kunitaka KURAMOTO, Yu KIMURA, \\ Hirofumi TAGAMI, Atsushi INAYOSHI and Yasushi YAGI \\ Department of Surgery, Kumamoto Regional Medical Center
}

The postoperative condition of patients with early gastric cancer who underwent proximal gastrectomy reconstructed by jejunal pouch interposition (JPI group, $n=14$ ) was analized retrospectively in comparison with reconstruction by esophagogastrostomy (EG group, $\mathrm{n}=22$ ) during the same period, from 1996 to 2006. The operative time of the EG group (131 min) was significantly shorter than that of the JPI group (161 min). No significant difference was seen between the two groups in blood loss and postoperative stay. There was no significant difference in postoperative complications including anastomotic leakage, stenosis, pancreatitis, intestinal obstruction, and pneumonia. No significant difference was seen in clinical symptoms of heartburn, gastric fullness, vomiting, diarrhea, and Dumping syndrome. There was also no significant difference in food intake, nutrition status, and body weight loss change. Endoscopic examination one year after the operation showed no significant differences including reflux esophagitis, anastomotic stenosis, remnant gastritis, and bile regurgitation. A high incidence of food residue in the remnant stomach or jejunal pouch was found in JPI group (80.0\%), a significantly higher proportion than that found in EG group (14.3\%). JPI group showed no better results for postoperative symptoms than EG group. In terms of operation time and food residue, EG group was superior to JPI group. A simple and conventional reconstructive procedure by esophagogastrostomy should be indicated after proximal gastrectomy. 